Analitika: Jurnal Magister Psikologi UMA, Vol. 10 (2) Desember (2018)

ISSN: 2085-6601 (Print), ISSN: 2502-4590 (Online),

DOI: http://dx.doi.org/10.31289/analitika.v10i2.1788

\title{
ANALITIKA
}

Jurnal Magister Psikologi UMA

Available online http://ojs.uma.ac.id/index.php/analitika

\section{Hubungan Persepsi Keterampilan Mengajar Guru dengan Motivasi Belajar Siswa Akselerasi di Sekolah Menegah Atas Al-Azhar Medan}

\section{The Correlation Between Perception of Teacher Teaching Skills and Acceleration Students Motivation to Learn at The Senior High School Al-Azhar Medan}

\author{
Suri Handayani Damanik*1) \& Filia Dina Anggaraeni2) \\ 1) Program Studi Pendidikan Guru PAUD, Fakultas Ilmu Pendidikan \\ Universitas Negeri Medan, Indonesia \\ 2)Fakultas Psikologi, Universitas Sumatera Utara, Indonesia \\ Diterima: Agustus 2018, disetujui: Desember 2018, dipublish: Desember 2018
}

*Corresponding author: E-mail: suridamanik@gmail.com

\begin{abstract}
Abstrak
Penelitian ini bertujuan untuk mengetahui hubungan persepsi tentang keterampilan guru mengajar dengan motivasi belajar siswa kelas akselerasi untuk mata pelajaran sosiologi di SMA Swasta Al-Azhar Medan. Metode yang digunakan dalam penelitian ini adalah deskriptif korelasional, dengan menetapkan populasi penelitian adalah seluruh siswa kelas akselerasi SMA Swasta Al-Azhar Medan tahun ajaran 2009/2010, yaitu sebanyak 34 siswa. Metode pengambilan sampel yang digunakan adalah sampel total (total sampling) yakni seluruh anggota populasi dijadikan sampel. Data dikumpulkan menggunakan kuesioner dengan skala Likert. Reliabilitas alat ukur untuk persepsi tentang keterampilan guru mengajar adalah 0,941 dan untuk motivasi belajar adalah sebesar 0,864. Teknik analisis data yang digunakan adalah uji korelasi (Pearson Product Moment). Hasil penelitian menunjukkan bahwa terdapat hubungan yang signifikan antara persepsi tentang keterampilan guru mengajar dengan motivasi belajar siswa $(r=0,352)$. Kesimpulan penelitian ini menunjukkan bahwa persepsi tentang keterampilan guru mengajar berhubungan dengan motivasi belajar siswa kelas akselerasi untuk mata pelajaran Sosiologi di SMA Swasta Al-Azhar Medan.
\end{abstract}

Kata kunci: Motivasi Belajar, Keterampilan Guru Mengajar, Persepsi, Kelas Akselerasi

\begin{abstract}
The purpose of this research is to know the correlation between perception of teacher teaching skills and students motivation to learn Sociology at acceleration class of SMA Swasta Al-Azhar Medan. Method used in this research is descriptive correlation and the population is all of acceleration class students at SMA Swasta Al-Azhar Medan in 2009/2010, that is 34 students. Sampling method which is used in this research is total sampling (all of population member used as sample). Data collected by using the questionnaire with Likert Scale. The reliability of each instruments are 0,941 for perception of teacher teaching skills, and 0,864 for students motivation to learn. Method of data analyze is Pearson correlation test (Pearson Product Moment).The result of this research indicate that there is a significant correlation between perception of teacher teaching skills and students motivation to learn $(r=0,352)$. The conclusion indicate that the perception of teacher teaching skills relate to students motivation to learn Sociology at acceleration class of SMA Swasta Al-Azhar Medan.
\end{abstract}

Keywords: Motivation To Learn, Teaching Skills, Perception, Acceleration Class

How to Cite: Damanik, S.H. \& Anggaraeni, F.D. (2018), Hubungan Persepsi Keterampilan Mengajar Guru dengan Motivasi Belajar Siswa Akselerasi di Sekolah Menegah Atas Al-Azhar Medan, Analitika: Jurnal Magister Psikologi UMA, 10 (2): 60 - 68 


\section{PENDAHULUAN}

Layanan pendidikan menyangkut tentang keseluruhan upaya yang dilakukan untuk mengubah tingkah laku manusia demi menjaga kesinambungan dan peningkatan kualitas hidupnya. Layanan pendidikan merupakan salah satu program strategis jangka panjang yang senantiasa memerlukan perbaikan serta peningkatan kualitas yang tidak bisa dijalankan secara reaktif, sambil lalu dan sekenanya, melainkan mesti dengan cara proaktif, intensif, dan strategis (Sidi, 2001).

Layanan pendidikan yang bermutu akan menentukan tinggi atau rendahnya perolehan hasil belajar siswa. Selain itu, hasil belajar siswa berkaitan dengan seberapa besar siswa memiliki keinginan yang kuat untuk terlibat secara aktif dalam proses belajar. Keinginan yang kuat serta keterlibatan aktif dalam proses belajar menunjukkan kadar atau kondisi motivasi belajar yang dimiliki siswa (Sidi, 2001).

Kata motivasi digunakan untuk menjelaskan alasan orang melakukan sesuatu, membuat mereka tetap melakukannya, dan membantu mereka dalam menyelesaikan tugas-tugas (Pintrich, 2003). Terdapat dua aspek motivasi belajar yang dimiliki siswa, yaitu motivasi ekstrinsik dan motivasi intrinsik (Santrock, 2007). Motivasi ekstrinsik yaitu melakukan sesuatu untuk mendapatkan sesuatu yang lain (cara untuk mencapai tujuan). Motivasi ekstrinsik sering dipengaruhi oleh insentif eksternal seperti imbalan dan hukuman. Misalnya, murid belajar keras dalam menghadapi ujian untuk mendapatkan nilai yang baik. Sedangkan motivasi intrinsik yaitu motivasi internal untuk melakukan sesuatu demi sesuatu itu sendiri (tujuan itu sendiri). Misalnya, murid belajar menghadapi ujian karena dia senang pada mata pelajaran yang diujikan itu.

Motivasi belajar siswa dapat dipengaruhi oleh berbagai faktor, seperti harapan guru, instruksi langsung, umpanbalik (feedback) yang tepat, hadiah, dan hukuman (Brophy, 2004). Beberapa faktor di atas yang mempengaruhi motivasi belajar berkaitan dengan keterampilan mengajar yang perlu dimiliki oleh seorang guru, seperti instruksi langsung dan pemberian umpanbalik. Selain itu, penelitian sebelumnya juga menunjukkan bahwa motivasi belajar siswa berhubungan dengan persepsi siswa terhadap cara mengajar guru (Tarmidi \& Hadiati, 2005) dan persepsi siswa terhadap kompetensi profesionalisme guru (Rangkuti \& Anggaraeni, 2005).

Kajian yang berkenaan dengan motivasi belajar siswa sebagaimana dilakukan oleh Susilowati (2004) pada kelas akselerasi di SMP Islam Al-Azhar 1 Jakarta menemukan bahwa terdapat $68,2 \%$ yang berminat pada pelajaran IPA dan $25 \%$ pada pelajaran IPS. Dari $25 \%$ siswa kelas akselerasi yang meminati pelajaran IPS diketahui bahwa motivasi siswa belajar adalah faktor pelajaran itu sendiri (38,1\%). Selebihnya, karena faktor guru $(33,3 \%)$, cara mengajar guru $(23,8 \%)$, suasana kelas $(4,8 \%)$, dan faktor lainnya (0\%).

Karakteristik motivasi belajar yang dimiliki oleh siswa berbakat berkaitan dengan konsistensi dalam 
menyelesaikan tugas-tugas yang menjadi minatnya, senang mengerjakan tugas secara independen dimana mereka hanya memerlukan sedikit pengarahan, serta ingin belajar, menyelidiki, dan mencari lebih banyak informasi (Heward, 1996). Oleh karena itu, guru yang berperan dalam menangani siswa berbakat, terutama bagi mereka yang ditempatkan dalam kelas akselerasi, lebih berperan sebagai fasilitator, sedangkan tanggungjawab belajar ada pada peserta didik (Widyorini, 2002).

Pencapaian hasil belajar yang tinggi oleh siswa tidak bisa dilepaskan dari standar proses yang menampilkan kualitas layanan pembelajaran. Untuk itu pencapaian hasil belajar siswa tidak dapat dielakkan dari keharusan menganalisis setiap komponen yang dapat membentuk dan mempengaruhi proses pembelajaran. Begitu banyak komponen yang dapat mempengaruhi kualitas pendidikan, seperti guru, siswa, kurikulum, metode, anggaran, fasilitas, evaluasi, dan sebagainya. Namun demikian, tidak mungkin upaya meningkatkan kualitas dilakukan dengan memperbaiki setiap komponen secara serempak. Hal ini selain komponenkomponen itu keberadaannya terpencar, juga sulit menentukan kadar keterpengaruhan setiap komponen. Diantara banyaknya komponen, yang selama ini dianggap sangat mempengaruhi proses pendidikan adalah komponen guru (Sanjaya, 2008).

Guru adalah unsur manusiawi dalam pendidikan. Guru adalah figur manusia sebagai sumber yang menempati posisi dan memegang peranan penting dalam pendidikan.
Penelitian menunjukkan bahwa lebih dari tiga puluh persen keberhasilan pendidikan yang ditunjukkan oleh indikator prestasi belajar siswa ditentukan oleh guru (Supriadi, 1998). Ketika banyak orang mempersoalkan masalah kualitas pendidikan, tidak dapat dielakkan bahwa figur guru menjadi unsur yang dibicarakan, terutama yang menyangkut persoalan pendidikan formal di sekolah. Hal ini memang wajar, sebab guru merupakan ujung tombak yang berhubungan langsung dengan siswa sebagai subjek dan objek belajar. Bagaimanapun baik dan idealnya kurikulum pendidikan, tanpa diimbangi dengan kemampuan guru dalam mengimplementasikannya, maka semuanya akan kurang bermakna. Oleh sebab itu, untuk mencapai standar proses pendidikan, sebaiknya dimulai dengan menganalisis komponen guru (Sanjaya, 2008).

Terdapat beragam peranan guru yang semuanya membutuhkan pengetahuan dan keterampilan dalam pelaksanaannya. Keterampilan guru mengajar merupakan salah satu jenis keterampilan yang harus dikuasai guru. Dengan memiliki keterampilan mengajar, guru dapat mengelola proses pembelajaran dengan baik yang berimplikasi pada peningkatan kualitas lulusan sekolah. Terdapat enam aspek yang menggambarkan keterampilan guru mengajar. Keenam aspek tersebut yaitu mengulas pembelajaran sebelumnya, memberikan materi baru, memberikan latihan dengan bimbingan guru, memberikan umpan balik (feedback), memberikan latihan mandiri kepada siswa, dan mengulas kembali materi 
yang telah diajarkan dengan interval berjarak (mingguan atau bulanan). Dengan adanya keenam aspek tersebut, guru diharapkan dapat menciptakan kondisi yang mendorong atau menumbuhkan semangat siswa untuk melakukan aktivitas belajar dengan baik (Pintrich \& Schunk, 2002).

Sehubungan dengan fenomena lapangan, guru-guru yang mengajar di kelas akselerasi SMA Swasta Al-Azhar Medan memiliki kapasitas intelektual di atas rata-rata dan lebih kompeten. Hal ini disebabkan guru-guru tersebut harus mengikuti psikotes, lulus sertifikasi guru, serta diutamakan yang telah mengikuti program master jika ingin mengajar di kelas akselerasi SMA Swasta Al-Azhar Medan. Dilihat dari aspek keterampilan guru mengajar, motivasi belajar siswa rendah pada mata pelajaran sosiologi walaupun kriteria kemampuan guru mengajar sama karena sebelumnya mereka mengikuti seleksi yang cukup ketat. Jika diasumsikan kemampuan guru mengajar sudah relatif baik, maka hal yang mungkin berkaitan dengan motivasi belajar siswa adalah persepsi siswa tentang kemampuan guru mengajar yang tampak pada keterampilan guru mengajar.

Persepsi adalah proses dimana kita mengorganisasi dan menafsirkan pola stimulus dalam lingkungan (Atkinson, 1997). Ittelson (dalam Bell dkk, 1996) menyatakan bahwa terdapat empat aspek dari persepsi, yaitu kognitif (berpikir), afektif (emosional), interpretasi, dan evaluatif. McCombs, et al (dalam Santrock, 2007) menemukan bahwa siswa yang merasa didukung dan diperhatikan oleh guru lebih termotivasi untuk melakukan kegiatan akademik daripada siswa yang tidak didukung dan diperhatikan gurunya. Dalam kaitannya dengan bidang studi sosiologi, persepsi tentang keterampilan guru mengajar adalah proses kognitif, afektif, interpretasi, dan evaluatif yang diberikan siswa mengenai stimulus yang diberikan oleh guru berupa metode dan keterampilan guru sosiologi dalam menjalankan profesi keguruannya, terutama dalam hal melaksanakan proses belajar mengajar bidang studi sosiologi di kelas. Berdasarkan latar belakang di atas peneliti merasa perlu untuk melakukan penelitian dengan judul "Hubungan Persepsi Tentang Keterampilan Guru Mengajar dengan Motivasi Belajar Siswa Kelas Akselerasi Untuk Mata Pelajaran Sosiologi di SMA Swasta Al-Azhar Medan".

\section{METODE PENELITIAN}

Metode yang digunakan dalam penelitian ini adalah metode korelasi. Hal ini karena penelitian ini bertujuan untuk melihat hubungan antara persepsi tentang keterampilan guru mengajar dengan motivasi belajar siswa kelas akselerasi untuk mata pelajaran sosiologi di SMA Swasta Al-Azhar Medan.

Batasan mengenai motivasi belajar dalam kajian ini lebih difokuskan pada motivasi belajar ekstrinsik, yaitu dorongan yang dimiliki siswa dalam melakukan aktivitas belajar yang dikarenakan adanya pengaruh eksternal, seperti untuk mendapatkan imbalan dan menghindari hukuman. Motivasi belajar diukur dengan menggunakan skala motivasi belajar berdasarkan teori Santrock yang disusun sendiri oleh 
peneliti. Semakin tinggi skor subjek pada skala motivasi belajar siswa, maka semakin tinggi kecenderungan motivasi siswa dalam belajar. Sebaliknya, semakin rendah skor subjek pada skala motivasi belajar siswa, maka semakin rendah kecenderungan motivasi siswa dalam belajar.

Sedangkan batasan tentang persepsi dalam kajian ini adalah adanya proses kognisi, afeksi, interpretasi, dan evaluasi siswa mengenai keterampilan guru melaksanakan pembelajaran yang meliputi mengulas pembelajaran sebelumnya, memberikan materi baru, memberikan latihan dengan bimbingan guru, memberikan umpan balik (feedback), memberikan latihan mandiri, dan mengulas kembali materi yang telah diajarkan secara berkala.

Persepsi tentang keterampilan guru mengajar diukur dengan menggunakan skala persepsi tentang keterampilan guru mengajar berdasarkan teori Ittelson dan Pintrich \& Schunk yang disusun sendiri oleh peneliti. Semakin tinggi skor subjek pada skala persepsi tentang keterampilan guru mengajar, maka semakin positif kecenderungan persepsi siswa tentang keterampilan guru dalam mengajar. Sebaliknya, semakin rendah skor subjek pada skala persepsi tentang keterampilan guru mengajar, maka semakin negatif kecenderungan persepsi siswa tentang keterampilan guru dalam mengajar.

Populasi dalam penelitian ini adalah seluruh siswa kelas akselerasi SMA Swasta Al-Azhar Medan tahun ajaran 2009/2010, yaitu sebanyak 34 siswa, sedangkan sampel penelitian ini adalah semua siswa yang termasuk dalam populasi (sampel total).

Alat ukur yang digunakan dalam penelitian ini adalah Kuesioner Motivasi Belajar dan Kuesioner Persepsi Tentang Keterampilan Guru Mengajar yang berbentuk Skala Likert. Masing-masing skala terdapat 13 aitem dan 64 aitem. Kedua kuesioner tersebut terdiri dari butir pernyataan berbentuk favorabel dan tidak favorabel, dengan menggunakan lima pilihan jawaban yaitu: Sangat Sesuai (SS), Sesuai (S), Ragu-Ragu (R), Tidak Sesuai (TS), dan Sangat Tidak Sesuai (STS). Pemberian skor untuk skala ini bergerak dari 5 sampai 1 untuk aitem favorabel, sedangkan untuk aitem tidak favorabel bergerak dari 1 sampai 5. Hasil uji coba alat ukur diperoleh reliabilitas sebesar 0,864 untuk kuesioner motivasi belajar. Dari 20 butir yang diuji cobakan terdapat 13 butir yang memenuhi kriteria $r \geq$ 0,275 . Sementara itu, reliabilitas untuk kuesioner persepsi tentang keterampilan guru mengajar sebesar 0,941. Hasil uji coba menghasilkan 64 butir yang memenuhi kriteria $r \geq 0,275$ dari 103 butir yang diujicobakan.

Data yang diperoleh dalam penelitian ini akan diolah dengan metode statistik. Pengujian hipotesis utama untuk penelitian ini menggunakan pearson product moment dengan mengunakan program SPSS for Windows versi 13.0. Sebelum data-data yang terkumpul dianalisa, terlebih dahulu dilakukan uji asumsi yang meliputi uji normalitas dan linearitas. Uji normalitas dilakukan dengan menggunakan uji KolmogorovSmirnov. Hasil untuk variabel motivasi belajar diperoleh nilai $\mathrm{p}=0.193$ dan 
untuk variabel persepsi tentang keterampilan guru mengajar $\mathrm{p}=0,993$. Hal ini berarti bahwa data penelitian dari kedua variabel tersebut terdistribusi normal. Sedangkan uji linearitas dilakukan dengan menggunakan ANAVA. Dari hasil uji linieritas antara persepsi tentang keterampilan guru mengajar dengan motivasi belajar, diperoleh nilai $\mathrm{p}$ $=0,015(\mathrm{p}<0,05)$. Hal ini menunjukkan bahwa kedua variabel penelitian tersebut memiliki hubungan yang linier.

\section{HASIL DAN PEMBAHASAN}

Hasil penelitian utama menunjukkan bahwa ada hubungan antara persepsi tentang keterampilan guru mengajar dengan motivasi belajar siswa kelas akselerasi untuk mata pelajaran sosiologi di SMA Swasta AlAzhar Medan. Kesimpulan ini diperoleh dari hasil uji hipotesis dengan nilai koefisien korelasi ( $r$ ) sebesar 0,352 dan $\mathrm{p}=0,041$.

Hasil penelitian juga menunjukkan bahwa sebagian besar subjek penelitian memiliki motivasi belajar yang sedang yaitu sebesar $76,4 \%$. Selebihnya, $11,8 \%$ subjek penelitian memiliki motivasi belajar tinggi, dan $11,8 \%$ memiliki motivasi belajar yang rendah.

Berdasarkan hasil penelitian juga diperoleh sebesar 73,5\% dari subjek penelitian memiliki persepsi yang raguragu mengenai keterampilan guru dalam mengajar. Subjek penelitian yang memiliki persepsi tentang keterampilan guru mengajar yang positif sebesar $14,7 \%$, dan yang memiliki persepsi negatif mengenai keterampilan guru mengajar yaitu sebesar 11,8\%.
Hasil pengujian hipotesis menyatakan bahwa Ho ditolak, sehingga Ha diterima karena $\mathrm{t}$ hitung $>\mathrm{t}$ tabel. Hal ini menunjukkan bahwa terdapat hubungan yang signifikan antara persepsi tentang keterampilan guru mengajar dengan motivasi belajar. Hasil pengujian korelasi antara persepsi tentang keterampilan guru mengajar dengan motivasi belajar siswa menunjukkan bahwa $r=0,352$. Dengan menggunakan kriteria interpretasi harga $r$ menurut Hadi (2000), ternyata hubungan persepsi tentang keterampilan guru mengajar dengan motivasi belajar tergolong rendah.

Temuan penelitian bahwa terdapat korelasi yang rendah antara persepsi tentang keterampilan guru mengajar dengan motivasi belajar siswa sejalan dengan penjelasan Brophy (2004) yakni terdapat sejumlah faktor yang dapat mempengaruhi motivasi belajar siswa seperti harapan guru, instruksi langsung, umpanbalik (feedback) yang tepat, hadiah, dan hukuman. Pintrich \& Schunk (2002) menyatakan bahwa instruksi langsung dan pemberian umpanbalik (feedback) yang tepat merupakan bagian dari keterampilan guru mengajar. Studi ini menemukan rendahnya korelasi antara persepsi tentang keterampilan guru mengajar terhadap tumbuhnya motivasi belajar siswa disebabkan oleh masih adanya faktor lain yang mempengaruhi seperti harapan guru, hadiah, dan hukuman.

Temuan kajian ini menunjukkan bahwa kecenderungan rata-rata skor pada variabel persepsi tentang keterampilan guru mengajar lebih ke 
arah ragu-ragu berdasarkan interpretasi skala skor yang digunakan. Korelasi antara persepsi siswa tentang keterampilan guru mengajar dengan motivasi belajar siswa rendah karena siswa berpersepsi ragu-ragu terhadap keterampilan guru sosiologi dalam pembelajaran. Hal ini berarti bahwa siswa ragu bahwa guru sosiologi melakukan atau tidak berbagai keterampilan mengajar atau seandainya guru melakukan maka siswa ragu apakah hal yang dilakukan guru sosiologi merupakan bentuk dari keterampilan mengajar. Untuk lebih jelasnya, skor rata-rata pada variabel persepsi siswa tentang keterampilan guru mengajar dapat dilihat pada tabel berikut ini:

Tabel 1. Skor Rata-Rata pada Persepsi Siswa Tentang Keterampilan Guru Mengajar

\begin{tabular}{|c|c|c|}
\hline No. & Aspek & $\begin{array}{l}\text { Skor } \\
\text { Rata-Rata }\end{array}$ \\
\hline 1. & $\begin{array}{l}\text { Mengulas pembelajaran } \\
\text { sebelumnya }\end{array}$ & 3,511 \\
\hline 2. & Memberikan materi baru & 3,588 \\
\hline 3. & $\begin{array}{l}\text { Memberikan latihan dengan } \\
\text { bimbingan guru }\end{array}$ & 3,24 \\
\hline 4. & $\begin{array}{l}\text { Memberikan umpan balik } \\
\text { (feedback) }\end{array}$ & 3,506 \\
\hline 5. & $\begin{array}{l}\text { Memberikan } \\
\text { mandiri }\end{array}$ & 3,113 \\
\hline \multirow[t]{2}{*}{6.} & $\begin{array}{l}\text { Mengulas } \\
\text { pembelajaran } \\
\text { berkala }\end{array}$ & 3,046 \\
\hline & Skor Rata-Rata Keseluruhan & 3,334 \\
\hline
\end{tabular}

Data pada tabel 1 menunjukkan bahwa di antara enam aspek keterampilan guru mengajar yang dipersepsi oleh siswa, terdapat tiga aspek yang skor rata-ratanya di bawah skor rata-rata seluruh aspek yang dinilai yaitu: (1) aspek pemberian latihan dengan bimbingan guru, (2) aspek pemberian latihan mandiri, dan aspek mengulas kembali pembelajaran secara berkala. Ketiga aspek tersebut mendukung temuan penelitian yakni persepsi siswa tentang keterampilan guru mengajar dengan motivasi belajar ekstrinsik siswa menjadi rendah karena siswa memiliki persepsi yang ragu-ragu terhadap keterampilan guru sosiologi dalam melaksanakan pembelajaran.

Data hasil penelitian tentang motivasi belajar, menunjukkan bahwa aspek keinginan mendapatkan imbalan memiliki rata-rata skor yang lebih rendah dibanding rata-rata skor total seluruh aspek. Hal ini dapat dimaknai bahwa siswa cenderung untuk menghindari hukuman dalam melakukan kegiatan belajar daripada mendapatkan imbalan. Untuk lebih jelasnya data-data tersebut dapat dilihat pada tabel berikut:

Tabel 2. Skor Rata-Rata pada Motivasi Belajar

\begin{tabular}{llrl}
\hline No. & Aspek & $\begin{array}{l}\text { Rata-Rata } \\
\text { Skor }\end{array}$ \\
\hline 1. & $\begin{array}{l}\text { Untuk } \\
\text { imbalan } \\
\text { 2. }\end{array}$ & $\begin{array}{l}\text { Untuk } \\
\text { hukuman }\end{array}$ & 3,586 \\
\hline \multicolumn{2}{l}{ Rata-Rata Skor Total } & 3,017 \\
\hline
\end{tabular}

Dengan demikian, hasil penelitian tentang motivasi belajar yang diperoleh mendukung hipotesis penelitian bahwa terdapat hubungan yang signifikan antara persepsi tentang keterampilan guru mengajar dengan motivasi belajar siswa kelas akselerasi untuk mata pelajaran sosiologi di SMA Swasta AlAzhar Medan.

Hasil penelitian ini mungkin belum dapat dinyatakan sebagai kenyataan sebenarnya dari subjek yang diteliti. Selain karena peneliti tidak menggunakan alat ukur selain skala 
psikologis, dapat terjadi kemungkinan bahwa alat ukur berupa skala psikologis yang digunakan untuk mengukur variabel-variabel persepsi tentang keterampilan guru mengajar dan motivasi belajar belum mengungkap kenyataan yang ada di dalam diri subjek secara menyeluruh. Hal ini dapat dikarenakan jumlah butir yang terbatas dari setiap aspek variabel untuk dapat mengungkap kedua variabel tersebut sesuai kenyataan yang sebenarnya pada diri subjek. Selain itu format pilihan jawaban yang disediakan pada masingmasing alat ukur berjumlah lima jenjang (Sangat Tidak Sesuai, Tidak Sesuai, RaguRagu, Sesuai, dan Sangat Sesuai).

Format pilihan jawaban dengan lima jenjang, yang memiliki pilihan di tengah, sangat rentan untuk menimbulkan central tendency pada diri subjek. Menurut Azwar (2000), central tendency adalah responden akan cenderung memilih jawaban yang berada di tengah sehingga data mengenai perbedaan di antara responden menjadi kurang informatif. Untuk meminimalisir hal tersebut, peneliti telah menyampaikannya pada saat administrasi pengisian kuesioner, dimana subjek penelitian diminta untuk benar-benar merespon sesuai dengan keadaan yang sebenarnya dan jangan langsung memutuskan untuk memilih jawaban yang berada di tengah. Jika dilihat dari hasil penelitian yang diperoleh, walaupun sudah dilakukan usaha untuk menimalisir central tendency, sedikit banyaknya mungkin saja terjadi hal tersebut yang merupakan salah satu keterbatasan dari penelitian ini.

\section{SIMPULAN}

Berdasarkan hasil analisis data yang telah dilakukan pada bagian sebelumnya, maka dapat ditarik kesimpulan penelitian bahwa terdapat hubungan yang signifikan antara persepsi tentang keterampilan guru mengajar dengan motivasi belajar siswa kelas akselerasi untuk mata pelajaran sosiologi di SMA Swasta Al-Azhar Medan. Persepsi siswa kelas akselerasi SMA Swasta Al-Azhar Medan tentang keterampilan guru mengajar tampak bervariasi, yakni memberikan persepsi positif sebesar $14,7 \%$, ragu-ragu dalam mempersepsi sebesar 73,5\%, dan persepsi yang negatif sebesar 11,8\%. Motivasi belajar di kalangan siswa kelas akselerasi SMA Swasta Al-Azhar Medan yakni motivasi belajar tinggi $(11,8 \%)$, sedang $(76,4 \%)$, dan rendah $(11,8 \%)$.

\section{DAFTAR PUSTAKA}

Arikunto, S (2002). Prosedur Penelitian, Suatu Pendekatan Praktek. Jakarta: PT Rineka Cipta.

Atkinson, R.L, dkk (1997). Pengantar Psikologi Edisi Kedelapan. Jakarta: Erlangga.

Azwar, S. (2000). Penyusunan Skala Psikologi. Yogyakarta: Pustaka Pelajar. (2004). Reliabilitas dan Validitas. Yogyakarta: Pustaka Pelajar.

Bell, P.A. dkk (1996). Environmental Psychology 4th Edition. Florida: Harcourt Brace College Publishers.

Borich, G.D. (1996). Effective Teaching Methods 3th Edition. New Jersey: Prentice-Hall, Inc.

Brophy, J. (2004). Motivating Students to Learning. New Jersey: Lawrence Erlbaum Associates.

Elliot, S.N. dkk (1999). Educational Psychology (Effective Teaching Effective Learning). Singapore: McGraw-Hill.

Hadi, S. (2000). Metodologi Research. Yogyakarta: ANDI.

Hawkins, D.I. dkk (2007). Consumer Behavior. New York: The McGraw-Hill Companies, Inc. 
Heward, W.L. (1996). Exceptional Children $5^{\text {th }}$ Edition (An Introduction to Special Education). New Jersey: Prentice-Hall, Inc. Irwanto. (2002). Psikologi Umum (Buku Panduan Mahasiswa). Jakarta: PT. Prenhallindo.

Rangkuti \& Anggaraeni. (2005). Hubungan Persepsi Tentang Kompetensi Profesional Guru Matematika dengan Motivasi Belajar Matematika pada Siswa SMA. Psikologia Volume 1 No.2 Desember 2005. Medan: Fakultas Kedokteran USU.

Pintrich, P.R. (2003). Motivation and Classroom Learning. New Jersey: John Wiley \& Sons, Inc.

Pintrich, P.R. \& Schunk, D.H. (2002). Motivation in Education (Theory, Research, and Application). New Jersey: Prentice-Hall, Inc.

Santrock, J.W. (2007). Psikologi Pendidikan Edisi Kedua. Jakarta: Prenada Media Group.

Sanjaya, W. (2008). Kurikulum dan Pembelajaran. Jakarta: Prenada Media Group.

Sardiman, A.M. (2000). Interaksi \& Motivasi Belajar Mengajar. Jakarta: PT. Raja Grafindo Persada.

Sidi, I.D. (2001). Menuju Masyarakat Belajar (Menggagas Paradigma Baru Pendidikan). Jakarta: Paramadina.

Somantri, T.S. (2006). Psikologi Anak Luar Biasa. Bandung: PT. Refika Aditama.
Sundayana, R. (2009). Teknik Sampling dalam Penelitian (online), http://www.sundayana.web.id/tekniksampling-dalam-penelitian.html. Tanggal Akses: 3 Maret 2010 Pukul 18.30.

Supriadi, D. (1999). Mengangkat Citra dan Martabat Guru. Yogyakarta: Adicita Karya Nusa.

Susilowati, G. (2004). Siswa Kelas Akselerasi Lebih Meminati IPA (online), http://www.ssffmp.or.id/suplemen/cetak detail.asp?mid=1\&id=153194\&kat_id=105\&k at_id1 $=151 \&$ kat_id $2=192$. Tanggal Akses: 22 Juli 2009 Pukul 15.36.

Syah, M. (2003). Psikologi Belajar. Jakarta: PT. Raja Grafindo Persada.

Tarmidi \& Hadiati. (2005). Prestasi Belajar Ditinjau dari Persepsi Siswa Terhadap Iklim Kelas pada Siswa yang Mengikuti Program Percepatan Belajar. Psikologia Volume 1 No. 1 Juni 2005. Medan: Fakultas Kedokteran USU.

Uno, H. (2006). Orientasi Baru dalam Psikologi Pembelajaran. Jakarta: Bumi Aksara.

Widyorini, E. (editor) (2002). Anak Berbakat Tantangan di Era Global. Semarang: Penerbitan Universitas Katolik Soegijapranata.

Winataputra, U.S. (2001). Strategi Belajar Mengajar. Jakarta: Pusat Penerbitan Universitas Terbuka. 